\title{
Learning to Labour: an evaluation of internships and employability in the ICT sector
}

\begin{abstract}
The employability of graduates is often reduced to lists of de-contextualised skills that graduates may or may not have and which may or may not translate to prized graduate positions. Recently, internships have become the way in which graduates acquire and demonstrate work-readiness to potential employers. This article examines a particular type of internship in the ICT sector, namely placements incorporated in degree education. The findings suggest that while internships can enhance employability and indeed be a mechanism for accessing permanent jobs, more often, instead of 'learning to labour', interns are expected to be productive workers. A mini labour market operates at the undergraduate level that advantages those already possessed of the required soft skills. The emphasis on soft skills signals a shift in the nature of ICT work with attendant implications for education of workers in this sector, revealed by anchoring employability to particular labour process(es).
\end{abstract}

\section{Introduction}

In the context of a graduate labour market, employability represents the aspirations of a number of parties concerned with the transition from higher education to work. Policymakers are keen to realise the knowledge economy vision by increasing the supply of graduates, and less keen to intervene in demand for graduates (Ashton and Sung, 2010); universities are interested in graduate destinations, used as a measurement criterion in rankings (Marginson, 2006); educators consequently become involved in including transferable skills into curricula (David, 2011). Meanwhile, employers continue to revise the skills required by graduates (Hesketh, 2000). Graduates themselves, it seems, are acutely aware of labour market competition and accordingly adopt strategies to differentiate themselves from their peers in a job market where, some argue, class-based inequalities persist (Brown, 2000; Reay et al., 2010). Moreover, rising graduate unemployment and debt place additional pressures on university leavers. A recent study noted that 'employers, education providers and youth live in parallel universes' (Mourshed et al., 2012:18), citing survey evidence from ten countries where fewer than $50 \%$ of young people and employers believe that graduates are work-ready, yet $72 \%$ of educators claim that they are content 
with the graduates that their institutions produce. On closer examination, the notion of employability therefore raises questions regarding the extent to which graduates are, or should be, work-ready and if so, how and where work-readiness is acquired.

This paper examines an aspect of employability which seeks to satisfy the various interest groups involved, namely the use of internships incorporated in university degree programmes. Internships have been gaining popularity as a way for students to acquire and demonstrate work-related skills. However, in practice the use of internships has raised concerns related to the potential exploitation of vulnerable young workers (Costea et al., 2012). The research described in this article, aimed to systematically explore the value of such internships, in the Information and Communication Technology (ICT) sector in England and Wales. ICT is argued to be symbolic of the knowledge economy covering a range of occupations with various requirements (Adams and Demaiter, 2008) and is therefore an interesting site for research. ICT professions are not only the classical computer professions (software, hardware and networking), but also emerging professions in the areas of internet services and multimedia products, specialised business applications (e-commerce platforms) and user-related software development (e-learning, bio-informatics, electronic archiving).

The paper begins by exploring the tensions in existing literatures on employability, followed by a brief discussion of the particular issues associated with employability in the ICT sector. Data for the study focus on the pragmatics of internships, discussing how interns are selected and the internship experience, concluding with a discussion of the value of internships to research on employability. The findings suggest that the internship experience is very much dictated by the attitude of employers towards interns. Although all participants were largely positive about the potential for internships to enhance employability, there is a 'shadow of exploitation' in that many employers use interns as a source of cheap labour constructing an employment relationship that takes advantage of the interns' willingness and need to acquire relevant work experience. More significantly, due to the importance of soft skills in the selection of interns and their success during the internship programme there is clear evidence that students from middle class backgrounds are being advantaged. 


\section{Changing Nature of ICT Work and Skill}

Information and communication technologies (ICT) have been at the heart of economic changes for more than two decades with policy makers continually reinforcing the importance of the ICT sector to the economy (Warhurst et $\mathrm{al}_{,}, 2006$ ). It has been argued that economic competitiveness relies on productivity level and in the knowledge economy, the ICT sector is believed to determine productivity (Antonelli, 1999). As a result, the economic competitiveness of a country may depend on the vibrancy of its ICT sector. Holtgrewe (2014) suggests that the pervasiveness of technological change in and across industries, means that work practices developed in the ICT sector reach beyond its boundaries, so that it becomes representative of the 'future of work' ( $p 9$ ).

Within the UK, there are over 144,000 ICT-dedicated organisations and 1.5 million people within Information Technology and Telecoms, equivalent to about one in twenty of the working population (e-skills, 2012). The number of people working in the ICT sector has gradually increased over the last ten years (Table One). However, the trend towards global outsourcing means that ICT work is increasingly precarious and the nature of ICT work is also changing (Holtgrewe 2014). With development and maintenance work often being outsourced to developing countries, the concentration of work within the UK has centred on the implementation, adaptation, sales and placement of the technology meaning that ICT workers have to be 'hybrids' who understand the technology but can also work with people (Woodfield, 2000). In fact, the British Computing Society (BCS) identified the need for hybrid worker/managers nearly two decades ago (Brackley, 1996) arguing that ICT workers need to be able to interact with both customers and colleagues, for which they have to possess the requisite social and business skills. Empirical research has also identified an increasing need for ICT workers with soft skills as opposed to high level technical abilities (Marks and Scholarios, 2007).

\begin{tabular}{|l|l|l|l|}
\hline & \multicolumn{2}{|l|}{ Numbers Employed } & \\
\hline Job Description & $\mathbf{2 0 0 1}$ & $\mathbf{2 0 1 1}$ & Change (\%) \\
\hline ICT Managers & 223,000 & 285,000 & $28 \%$ \\
\hline $\begin{array}{l}\text { IT Strategy \& Planning } \\
\text { Professionals }\end{array}$ & 128,000 & 137,000 & $7 \%$ \\
\hline
\end{tabular}




\begin{tabular}{|l|l|l|l|}
\hline Software Professionals & 314,000 & 370,000 & $18 \%$ \\
\hline $\begin{array}{l}\text { IT Operations } \\
\text { Technicians }\end{array}$ & 128,000 & 121,000 & $-6 \%$ \\
\hline $\begin{array}{l}\text { IT User Support } \\
\text { Technicians }\end{array}$ & 73,000 & 65,000 & $-11 \%$ \\
\hline $\begin{array}{l}\text { Database Assistants \& } \\
\text { Clerks }\end{array}$ & 102,000 & 36,000 & $-65 \%$ \\
\hline Telecoms Engineers & 65,000 & 55,000 & $-16 \%$ \\
\hline $\begin{array}{l}\text { Line Repairers \& Cable } \\
\text { Jointers }\end{array}$ & 15,000 & 5,000 & $-64 \%$ \\
\hline Computer Engineers & 47,000 & 41,000 & $-12 \%$ \\
\hline
\end{tabular}

Table One: Changing nature of skill in the ICT sector. E:skills, 2012

The changing nature of ICT work in the UK can clearly be seen in Table One, demonstrating a gradual shift not only from more routinized to higher level work but also heralding a change in the nature of skills from technical knowledge to a combination of technical and soft/managerial skills. This shift has enabled UK firms to expand services rapidly but has also raised questions on the forms and combinations of skills required for entry (Donnelly et al 2011).

Education provision for ICT workers has expanded alongside demand for skills, although Marks and Huzzard (2010:171) cite data from e-skills which notes 'a substantial fall in those with IT-related degrees entering professional work from 47 per cent in 2000 to 28 per cent in 2004', reflecting the need for a broader skills base to work in the sector (as opposed to a narrow focus on technical skills). Alongside this trend, there is evidence of a decline in applications to IT courses (Donnelly et al 2011). Adams and Demaiter (2008) suggest that although credentialed knowledge and skills are established in the sector, technical skills can be acquired through routes other than IT-related degrees reflecting a potential disconnect between the education provided by universities and industry requirements. Whilst technical degrees in universities attempt to embed business skills in the curriculum, employers still complain that graduates are lacking in both business and technical skills (Hagan, 2004).

\section{Graduate Employability in ICT Sector}

Understanding the match (or sometimes mismatch) between graduate skills and labour market requirements is an established field of study, often couched in broader debates about employability. One of the challenges of assessing graduate employability, whether in ICT or other non-vocational disciplines, relates to more general discussions on the signalling 
capacity of qualifications (Machin and Vignoles, 2006). Numerous studies seek to identify and rank key features and skills in employability (e.g. Morley, 2007; Hesketh, 2000). Some confine research to graduate only surveys, asking questions on skills and knowledge utilisation in work, others seek the views of graduate employers on required skills and knowledge. An often overlooked aspect of graduate employability is the role of recruitment and selection in the transition from education to work (Keep and James, 2010). As gatekeepers, recruiters may have particular perceptions of suitability and frame these in normative terms, making subjective judgements on, for example, what degree classifications signal about work ethic (Morley, 2007). In a study of employer requirements, Morley ranks the information used in graduate recruitment practices, and prioritised in selection decisions, concluding that "employers increasingly want a complex combination of factors, which include academic achievement, and a range of skills and dispositions." (2007:205). Similarly, Hesketh (2000) asks employers to rank their preferred skills and to state the extent to which graduates possess these skills. He finds communication (verbal and written), ability to learn, problem solve and work in a team to be key across most sectors.

It could be argued that upon entry to the labour market, degrees become merely a ticket to entry into employment and success is related to the 'add-ons' that graduates demonstrate on their CV and in terms of their performance during the selection process. Yet, the picture appears more 'muddy' than a simplistic interpretation of the broader skills of a graduate. Mayhew et al., (2004) argue that higher education itself performs a screening function which maybe unrelated to knowledge and skills and that those from middle and upper class families tend to be privileged in terms of access to more elite universities which serve as a strong advantage in the labour market (Brown and Hesketh, 2004).

ICT work has traditionally attracted a large proportion of applicants from a working class background. Kelsall et al., (1972) found that most working class children looking for entrance into further or higher education are likely to choose technical subjects as these are closer to their parents' manual job experiences but also allow relatively stable labour market positions. Indeed, van de Werfhorst et al., (2003) established that in the UK, the children of the professional classes were far more likely to enter the traditional professions of law and medicine than engineering, and that these degree courses were still dominated 
by the children of the established professional classes. Marks and Baldry (2009) examined the class position and class identity of a group of Scottish software workers. The majority of participants in this study defined their background as working class. Entry into this occupational group was seen as a less marked transition from their existing location in the working classes. Marks and Baldry (2009) argue that software work (and other ICT occupations) is attractive to those individuals with working class origins as it offers openaccess socio-economic mobility without the cultural barriers presented by the traditional professions. As a consequence, it could be argued that advantaged entry into the labour market through informal pathways open to the upper and middle classes are less likely to impact on ICT workers and a straight forward combination of a good degree and softer skills are likely to enhance employability.

\section{Internships and Employability}

Within a background of increasing competition in the graduate labour market and uncertainty over the exact combination of skills required, work experience has become increasingly important in the selection of graduates. Of course student employment has always been a financial necessity for many, often to the detriment of academic success (Golden and Baffoe-Bonnie, 2011). More recently, however, work experience is primarily used to distinguish amongst otherwise equally qualified graduates, prompting an internship labour market for undergraduates, consisting of work that is often unpaid and of questionable value (Page, 2012). Employers, particularly within the creative industries, have been quick to exploit young workers, keen to enhance their CVs by offering mostly unpaid internships (Siebert and Wilson, 2013). A recent survey by the National Union of Students found that students from wealthy backgrounds were three times as likely to have undertaken unpaid internships - having the resources and support to gain experience by taking on such internship arrangements - introducing a further source of inequality in the graduate labour market (NUS, 2012;p. 2012). Yet, internships are not entirely a new phenomenon, particularly in ICT-related course where universities have routinely incorporated a year in industry to supplement education, although in England and Wales this only applies to $20 \%$ of students on ICT-based degrees (HESA, 2011). 
In Germany, where mandatory internships are undertaken by over half the student population, positive effects are said to include a smooth transition from higher education to work, and exposure to the working environment, often leading to jobs after graduation (Klein and Weiss, 2011). However, Klein and Weiss found no positive labour market effects from compulsory internships and no labour market advantage for graduates from lower educational backgrounds, suggesting that work experience does not over-ride academic ability. In general terms, these writers warn against mandatory placements arguing that they may be de-motivating, although also recognising that the quality of students varies as does the quality of placements and their evaluation.

In the UK, Wilton examines the value of placements as part of a university degree in business and management (Wilton, 2012). Again, he questions the 'received wisdom' that placements necessarily enhance transferable skills and have a positive labour market advantage. Wilton calls for more work on the relationships between work placements and graduate outcomes, particularly in terms of defining what a 'good' placement entails and the ways in which the beneficial aspects of placements are to be demonstrated in a competitive labour market (Wilton, 2012). Both these studies seem to suggest that while placements can enhance employability, they are not sufficiently well understood.

\section{Methodology}

In this paper, we seek to explore the value of year-long industrial placements incorporated in university degrees in the ICT sector. We consider the placements as a mechanism for enhancing employability but also examine, in a relatively 'open-access' occupational group, whether internships privilege any particular groups of students. In a sector where the demands of work are moving towards an emphasis on soft skills, universities may have difficulties in providing these skills. So, it could be argued that placements are an ideal strategy to facilitate transitions from education to work. Internships are a component of the employability agenda which encourages closer ties between the worlds of education and work. Placements undertaken as part of a degree programme perhaps acknowledge 
that situated learning is a key component of employability in the ICT sector, something that previous research has revealed (Baldry et al 2007).

This research centred on individuals who had been through the e-skills internship programme in England and Wales between 2009 and 2011. This e-skills programme (now the e-skills Professional Placement Scheme) was explicitly aimed at boosting student employability. It allowed existing placement arrangements to be accredited through e-skills with the addition of a set of best practices and prescribed learning outcomes. Students were monitored by their university during the placement using e-skills criteria and, based on satisfactory completion, eligible for a national certificate. The learning aims of the placement were entirely based on personal (e.g. communication and teamwork) and business skills (e.g. time management and project management) rather than technical skills.

An online survey was distributed to all individuals who had participated in these accredited internships during the pilot and first years of the programme. Three hundred and fifty four individuals were initially surveyed. Fifty eight emails were returned due to invalid and e-mail addresses, leaving 296 usable e-mail addresses. Forty six individuals completed the survey resulting in a response rate of $15.5 \%$. However, many of the email addresses for interns were their university contract details and therefore out of use after graduation, making it difficult to calculate an accurate response rate. Due to the modest survey response, for the purpose of this paper we will focus on more general responses from the survey, as well as the follow-up interviews. However, for clarity, $81 \%$ of survey respondents are male, slightly less than the $84 \%$ reported for the industry as a whole (e-skills 2014). Fifty seven per cent have degrees in IT/Computer Science/Software Development with the remaining $43 \%$ also having a Business and/or Management component to their degree. Interestingly, $18 \%$ are employed full-time by their placement organisation, a point which will be revisited below.

A survey was also conducted with employers. One hundred and forty eight surveys were delivered to employers with 47 responding. This resulted in a $32 \%$ response rate. The only findings from this survey that are relevant to this paper are the responses to the questions on skills are characteristics that are desirable in internship students. 
Table Two details the demographic profiles of the survey respondents, a calculation based on the highest occupational group of parent, using the NS-SEC classification. A broad categorisation of the university attended is also given.

\begin{tabular}{|l|r|}
\hline University & \\
\hline Pre 1992 & 31.8 \\
\hline Post 1992 & 47.7 \\
\hline Don't Know & 20.5 \\
\hline Social Class, by parental occupation & \\
\hline 1 (Higher managerial, administrative and professional occupations) & 0 \\
\hline 2 (Lower managerial, administrative and professional occupations) & 26 \\
\hline 3 (Intermediate occupations) & 47 \\
\hline 4 (Small employers and own account workers) & 8 \\
\hline 5 (Lower supervisory and technical occupations) & 8 \\
\hline 6 (Semi-routine occupations) & 11 \\
\hline 7 ((Routine occupations) & 0 \\
\hline 8 (Never worked and long-term employed) & 0 \\
\hline
\end{tabular}

Table Two: Internship Survey Demographics

A representative sample of survey respondents was interviewed between August and September 2011. In addition, we interviewed people who managed the internships within the universities and employer representatives participating in the scheme. Hence, this interview data represents the views of interns (8), employers (13) and university representatives (5). Details of the interviewees are shown in Table Four.

\begin{tabular}{|l|l|l|l|}
\hline Pseudonym & Current Job Title & Sector & Gender \\
\hline Employer 1 & $\begin{array}{l}\text { Informational Change } \\
\text { Leader }\end{array}$ & Pharmaceuticals & Male \\
\hline Employer 2 & Data Analyst & Government Agency & Female \\
\hline Employer 3 & Database Manager & Government Agency & Female \\
\hline Employer 4 & Demand Manager & Pharmaceuticals & Female \\
\hline Employer 5 & $\begin{array}{l}\text { Technical Support } \\
\text { Manager }\end{array}$ & Software Development & Male \\
\hline Employer 6 & Consultant & Management Consultancy & Male \\
\hline Employer 7 & IT Manager & Insurance & Female \\
\hline Employer 8 & Development Manager & Higher Education & Male \\
\hline Employer 9 & IT Manager & Telecoms & Female \\
\hline
\end{tabular}

\footnotetext{
${ }^{1}$ As a result of the 1992 Education Reform Act in the UK, a considerable number of polytechnics were granted university status (hence pre and post 1992).
} 


\begin{tabular}{|l|l|l|l|}
\hline Employer 10 & Sales Director & IT Solutions & Male \\
\hline Employer 11 & IT Manager & Secondary Education & Male \\
\hline Employer 12 & IT Manager & Higher Education & Male \\
\hline Employer 13 & Business Owner & Digital Forensics & Male \\
\hline Intern 1 & Applications Developer & Pharmaceuticals & Male \\
\hline Intern 2 & Games Developer & Software Development & Male \\
\hline Intern 3 & IT Support & Manufacturing & Male \\
\hline Intern 4 & $\begin{array}{l}\text { Client Technical } \\
\text { Specialist }\end{array}$ & Computer Manufacturer & Female \\
\hline Intern 5 & Clerical worker & Local government & Male \\
\hline Intern 6 & $\begin{array}{l}\text { Part-time Software } \\
\text { Developer/Student }\end{array}$ & Healthcare & Male \\
\hline Intern 7 & Business Analyst & Pharmaceutical & Male \\
\hline Intern 8 & Graduate Trainee & Pharmaceuticals & Male \\
\hline Uni 1 & Lecturer in Management & Pre-1992 University & Male \\
\hline Uni 2 & Teaching Fellow & Pre-1992 University & Male \\
\hline Uni 3 & Placement Manager & Post-1992 University & Female \\
\hline Uni 4 & $\begin{array}{l}\text { Professor of Computer } \\
\text { Science }\end{array}$ & Post-1992 University & Male \\
\hline Uni 5 & Senior Lecturer & Post-1992 University & Male \\
\hline
\end{tabular}

Table Three: Interview Participant Details

Interviews lasted between 45 and 90 minutes and participants were asked questions on their present employment and involvement with placement organisations. In addition, university representatives and employers were asked to comment on placement provision, and the interns were questioned about their placement experiences. Interviews were recorded verbatim and transcribed and analysed thematically. The themes identified from the data are organising internships, the employer perspective, skills transfer and work content, all of which are presented and analysed in the following sections.

\section{Organising Internships}

Participating universities all offer a year in industry after the second year of studies with students returning for a final year at university after the placement. Some universities have a threshold qualification level for the placement year (for example, an average grade of $55 \%$ or more), others allow any students who have passed first and second year to apply. Although universities encourage students to take advantage of placements, they are rarely mandatory. Typically, 
"We encourage all our students to take up placements but at the end of the day, it's up to the students to actually apply for the places. We cannot guarantee any student a placement." [Uni 4]

In effect, the placement is an opportunity that creates a separate labour market at undergraduate level. Universities act as a conduit between students and employers in the manner of recruitment agencies. However, their remit is limited to facilitating placement opportunities.

"We advertise all the positions on our learning environments system, so if they want to do a placement they access them through that. On there it has a job description and details of how to apply. If it's a CV and covering letter it comes to us and we'll kind of monitor and manage that process in terms of chasing the employer if they've not come back with interest in anyone, or setting up interviews and trying to do as much of the admin as possible because that's one of the benefits we sell to the employer" [Uni 3]

Universities have to strike a delicate balance between offering sufficient numbers of placements and ensuring that the experience offered is indeed likely to provide material benefit to their students. 'Benefit' varies according to degree programme. Broadly, universities expect some sort of relevant experience for their students,

"For most students l'd expect there to be a programming content of some nature, whether it be web programming or high level language programming. For Business Information students that's perhaps not so important but it's got to be computer related" [Uni 2]

Particular universities reported difficulties in finding placement organisations for students, "we'll clutch at any straws, from anyone who comes our way" [Uni 1], others, keen to maintain their reputation in the marketplace, were more selective, "we didn't want to be embarrassed by sending poor students" [Uni 2]. However, universities often establish longterm relationships with organisations willing to offer placements, either through personal contacts made by staff members or via the university's reputation. A London-based academic commented on how placements had changed over time,

'There are some students who still go out and do the hard techie stuff, and we've always had students who have done the management consultancy type, problemsolving jobs as well but the number of people who employ IT graduates is now virtually everybody so, they'll go and work for anything from a building society to a furniture warehouse, simply because all these companies need people to work on intranets, internet things like that.' [Uni 4] 
Interns, however, tended to prefer placements situated close to university. The problem of finding accommodation away from family and friends seems to dissuade students from seeking placements at a distance. Students from higher social classes were more likely to have the resources to accept an internship away from home. Whilst there were some financial benefits to internships, interns were generally paid at a lower rate than full-time staff. Moreover, students were generally expected to pay half their tuition fees while on placement a source of concern to students and educators alike. The financial constraints to all students accessing the full range of internship opportunities reflect more general views on the reproduction of social inequalities in higher education (Bourdieu and Passeron, 1990), and are similar to the evidence on unpaid internships in the creative industries (Siebert and Wilson 2013).

Although students were paying reduced tuition fees whilst on placement, there was often limited contact with academics during that period. At a minimum, a university representative checked that the placement organisation offered a viable opportunity for the student, visited the student twice during their placement year, but as one intern commented, 'just to make sure I was still alive' [Intern 1]. Placements are assessed via a report submitted on returning to university and accredited accordingly

To all intents and purposes, students are 'set free' from university during their placement year and the initial matching of students to posts is crucial to the subsequent internship experience in terms of the type and level of work students undertake. From a university perspective,

"There is a strong element of self-selection in placements. You tend to get quite a decent match.... an awful lot of these roles, are well within the capability of most university students in fact. [Uni 1]

Whether this quote is an indictment of the quality of placements or an advert for the quality of students is open to debate. However, the impression given by the university contacts is that there is a hierarchy in the type of placements offered so that the 'best' students tend to go to large organisations with the remainder scrapping for the leftovers. In line with the findings of Klein and Weiss (2011), it appears that work motivation and social skills played the most significant role in selection, and that the status of the university attended was relatively unimportant in this context. 


\begin{tabular}{|l|r|r|}
\hline Skill & Desired skills & Rank \\
\hline A good range of 'soft' skills (e.g. communication skills) & 73.9 & 1 \\
\hline Interest in the subject & 60.9 & 2 \\
\hline Enthusiasm about your organisation & 43.5 & 3 \\
\hline A potential graduate recruit & 41.3 & 4 \\
\hline Ability to work on their own & 39.1 & 5 \\
\hline Good grades at university & 34.7 & 6 \\
\hline A clear understanding of your business and your business needs & 28.3 & 7 \\
\hline Previous work experience & 15.2 & $8(=)$ \\
\hline Technical Skills & 15.2 & $8(=)$ \\
\hline Studying at a good university & 6.6 & 9 \\
\hline
\end{tabular}

Table Four: Skills required in internships students (each employer noted their top three)

As indicated by the survey results reported in Table Four, employers are forthcoming about their requirements and expectations of interns, and clearly know what they want, frequently articulated in personal terms rather than in technical expertise, typically

"What we were looking for were people that through interview we could identify whether or not IT was a means to an end, whether it was a lifestyle or whether it was a career choice. And by lifestyle I mean people that cannot, you know it not a slur against people that work with computers and can only communicate with computers .....We were looking for the social skills, the interpersonal skills, their software and programming skills and I think just their confidence was a huge part of what we were looking for." [Employer 10]

So, undergraduate students are being assessed on their social skills and confidence, something that may be more likely to be associated with background than education per se. Indeed, technical skills and university attended seem to be relatively unimportant in the selection process echoing work on the graduate labour market, with personal attributes assuming primary importance at selection (Brown and Hesketh 2004).

Employability in terms of internships is very much employer-led and unsuccessful students may face a 'double whammy' of being unable to secure the very experience that may improve their future career opportunities. In effect, in the intern labour market those who are motivated, socially skilled and look likely to contribute to the organisation materially are successful. This evidence subtly changes the role of placements from an opportunity to develop employability skills to selection of those who already possess the required social skills.

Internships - the employer perspective 
In the same way that questions are raised on whether higher education's role is to provide a set of useful work-related skills, or confer credentials and contacts that signal general abilities (Adams and Demaiter 2008), parallel concerns arise in the role of internships. The reasons that employers offered placements vary from the instrumental, for example,

'We take 30 or 40 placement students each year, they're an important part of our organisation because, being brutally honest, they don't cost very much money but they add value, they're so enthusiastic. If we employed a full-time resource, a contract resource, it would probably cost us two or three times as much to get the same level of value as we get from each kid.' [Employer 1]

to the altruistic,

'I strongly feel that if a student doesn't get the chance to actually see the real world before they leave university then I think they miss out and I think, let's call it the social responsibility for a company to at least give some chance to some people. Because I think one of the aims of a placement should be that they pick up things that they wouldn't be able to get at university, the more they are willing to take on, the more they are given from that point of view. If a student is keen then we'll give them more things to do.'[Employer 5]

These varying attitudes suggest that placements may be either employer driven or student driven with clear implications for the whole experience. However, the majority of employers have a pre-defined set of expectations for placement students and often "use the placements as an extended interview process if you want to call it that." [Employer 5]. Employers regard students as potential future employees and make that plain to students from day one of their placement. The placement allows employers to mould students to particular workplace cultures and processes and to dangle the possibility of a job after graduation as an incentive to perform. From our survey participants, $18 \%$ achieved permanent jobs in their placement organisation and $70 \%$ stated that the internship experience had relevance to their current role.

This protracted selection process is understood by interns who report that they are keen to get as much experience as they can in the hope that they will be employed after graduation. Indeed, large organisations offer fast track routes into their graduate programme dependent on a recommendation from their placement supervisor. Many organisations offered training to placement students, with $55 \%$ of survey respondents noting that they had received training during their placement year, mostly centred on specific technical applications used in their workplace. Employers stated the benefits of providing training to 
interns in classic human resource development terms. Thus, placement students are assessed as productive workers and training given accordingly

"The thing is you have got to give them training. There's two ways you can use them, you can bring them in if you've got truly menial tasks to do and give them no training but the reality is to do that is ridiculous, these are bright kids, we've brought them in and they deserve to be invested in. If you show that you're committed to their development you just get so much more discretionary effort back." [Employer 1]

\section{The internship experience - skills transfer and work content}

The broader form and content of work undertaken by placement students is developed during the placement year. Perhaps understandably, students were often started with a 'low-risk' introduction to the organisation and the work.

"We start them with the testing side because they only deal with their colleagues so you don't have to drop them in at the deep end in talking to an end user." [Employer 5]

The students were 'tested' until they established their trustworthiness. In the majority of cases, interns were seen as having value to the organisation. Employers were candid about the organisational advantages brought by placement students,

'They are part of a team and we treat them as part of that team, not as sort of a junior member. They've come in and they've contributed some real tangible benefits.' [Employer 10]

Being treated as part of the team may be seen as placing a level of trust in the students' abilities, however it may also underline the expectation that students should deliver. Many employers did point out that it took some time for students to assimilate into the world of work which perhaps indicates the stressful nature of work in the ICT sector,

'getting punctuality, getting used to office politics, people falling out with each other, all those silly little things that are quite a shock to begin with..' [Employer 9]

All employers noted instances of poor punctuality, poor communication skills and insufficient technical knowledge in previous interns. Some expressed annoyance that the supplying university showed little interest in offering solutions for these 'problem' interns, 
so that on occasion, they were forced to leave a student to their own devices, 'sitting in a corner' for most of the year "because he was just not up to the work" [Employer 5]. It seems employers are quick to identify and keen to use and develop their high performing interns but less keen to spend time with those who might need additional help to become proficient. In this type of short-term employment relationship, there is no incentive for employers to plough resources into interns when they are easily replaceable.

More broadly, employers were also quick to complain that universities do not adequately prepare students for the workplace particularly in terms of written communication, for example,

'The real issue is written communication, it's not really being adequately taught. I don't think they are very well prepared to actually do a placement in the business sector, not in the way you would expect after doing 2 years of a technical subject'[Employer 13]

In the same way that recruiters may have heightened expectations of the skills that graduates should possess, employers seemingly make value judgements on the level of expertise that a student should possess (Morley 2007).

From the students' perspective, the experience was often about gaining a detailed understanding of how people work and how organisations operate in the ICT sector however difficult it might be to persuade professionals to share their knowledge,

'I learnt a lot of skills and I learnt how projects worked in real life. People who are really into technology, they're very passionate about what they know and they're very good at it, and it's very hard for them to teach other people what they know or to explain different concepts to them. So it's quite challenging to get them to explain things to you and to get their knowledge out of their head.' [Intern 4]

Employers frequently gave students 'real life' projects to work on during their placement and their task then became sourcing of appropriate information to complete the project. Clearly, some placement students rose to the challenge and all were enthusiastic about how much they learned during the placement year reporting, "doing an internship was the best career decision I made so far " [Intern 6]. As one of the male survey participants stated 'Having experience of customer facing and support skills was certainly a benefit, but the 
main benefit was the experience of being in a full-time role with people depending on the work I did to enable them to further their work'.

Although internships are ostensibly about students gaining work experience, the undercurrent of evaluating interns as future employees means that internal performance reviewing was fairly rigorous. Although often couched in terms of 'chats about progress', objectives were set and progress monitored against targets and expectations,

"I treat my intern as if they were a permanent member of staff so they get set the same sort of targets as everybody else gets set. They get a target review and get assessed against that." [Employer 7]

Most of the interns we spoke to seemed to have little problem with targets and indeed embraced the opportunity for development offered by the placement organisation,

I was able to drive the work, really to help me gain as much as I could from the placement. The PDP was really good so from that I identified areas where I thought I'm not really hitting this behaviour at the moment and I'd really like to have work that would help me achieve it. At the six-month stage I said to my manager, I really think that the project management work would be really useful in helping me achieve this aim.' [Intern 8]

While employers are clear what they want from placement students, and keen to offer an opportunity to gain some work experience, they see higher education solely in terms of its utility for their particular work requirements and environment and seem to expect universities to deliver their desires,

"It would be really cool if universities collaborated with the corporate world to understand what are the needs of the business sector that universities are not providing" [Employer 4]

The potential drawbacks involved in acceding to such employer demands are also evident,

"I'd say that computer science has been diluted over the years quite severely. The mathematics and electronics side of it has definitely disappeared. As a result certain types of jobs may disappear in the long run or only a very few universities will provide high level engineering and software development and the majority will become places where they effectively educate potential IT professionals but not software engineers." [Employer 5] 
These divergent views on what is actually required by the sector in terms of technical knowledge and skills reflect the variety in ICT work and the difficulties involved in designing curricula to cover all possible aspects of work in all contexts of employment. Interns are also aware of the potential mismatch between the educational and business environments,

"It's always changing, year to year, month to month, new things come out and new methods get implemented in offices. Obviously lecturers teaching computer science aren't in a real world company getting the knowledge and experience so at university, they tell you in theory what should happen but that never happens." [Intern 1]

It appears that the emphasis on social skills at recruitment reflects a trend in the nature of work that educators do not yet fully recognise. Communication with internal and external clients is becoming central to work in the sector and it is perhaps no co-incidence that the majority of interns in this study had undertaken joint degrees with a management component. There are clear differences in perceptions of what graduates need to know suggesting a poorly articulated sense of connections between education and work in this sector.

\section{Discussion and Conclusions: Evaluating internships in the ICT sector}

This study has sought to uncover the value of internships in the ICT sector. In particular, the aim was to shed light on varying interpretations of employability for the interest groups involved: universities tend to see placements as a way of inculcating employability and focus on the positive benefits, perhaps leaving less able students to suffer; employers have their eye on the productive capacity of placements students and students are desperate to use any means possible to gain an advantage in the labour market. There are clear measurable advantages from the internship programmes insofar as some students are provided with substantial work experience, acquiring skills during their placement and securing jobs with their placement organisation after graduating.

There is evidence that soft skills are emphasised at the recruitment and selection stage, followed through in the internship experience and in evaluation of the organisational benefits that intern students produce. This evidence supports earlier work on skills in the ICT sector (e.g. Marks and Scholarios, 2008;Marks and Huzzard, 2010) and signals a change 
in the overall skills requirements in the ICT sector. Yet, the competitive nature of the market for internships creates winners and losers. The students who can demonstrate soft skills are more likely to be successful in gaining internships, will subsequently receive more training and work experience at a higher level, and are more likely to achieve employment after graduating. The value attributed to soft skills must, however, be seen in the context of a gendered occupational landscape and does not seem to have attracted more women into the sector, instead it has rewarded men for displaying these skills (Kelan 2008). This paper suggests that a hierarchy emerges that is similar to work on the graduate labour market more generally (Brown and Hesketh, 2004). Brown and Hesketh model graduate employability as a combination of hard and soft currencies and note that the accompanying narrative of employability allows graduates to articulate their utility to particular organisations (2004:36). The same can be said of the market for internships with the implication that the war for talent in this sector is being waged before graduation. Employability in this context is synonymous with work-readiness and instead of internships being an opportunity for 'learning to labour' they are a mechanism by which already advantaged students maintain their privileged position.

Whilst we have argued that success in IT work is less class driven than traditional professional work (van de Werfhorst et al., 2003), the increasing relevance of social skills to the occupation is likely to mean a continuing trend of privileging those from higher social classes (Brown 2003). The data presented in Table Four indicates that employers do not favour students from more elite universities (typically associated with higher social classes), and analysis of our data shows only marginal benefit in attending a pre-1992 university for subsequent employment opportunity. There is, however, evidence that graduates from higher social classes are more likely to achieve employment on graduating $(41 \%$ of respondents in social classes 2 and 3 are in full-time work or education as opposed to $11 \%$ in social classes 4-7).

Despite previous calls that ICT work is open access, allowing social mobility for entrants from lower social classes (Marks and Baldry, 2009), the emphasis on internships for employability within the sector is compounding social class advantage. Advantage is displayed in a subtle manner with capital benefit including the financial resources to take the better placement opportunities and enhanced soft skills allowing access to the superior 
placements and in turn enhanced overall employability (Andrews and Higson, 2008) This benefit goes beyond the typical debates about advantages of the more elite educational institutions and access to unpaid internships (Brown and Hesketh 2004).

Employers view interns as potential employees, offering training and an opportunity to experience working life and ultimately offering jobs to those who contribute to the organisation. Yet, in attempting to evaluate the internship experience, we note a 'shadow of exploitation'. For critical scholars, the notion that interns are 'cheap labour', costing far less than other full-time staff, yet delivering the same if not more, is particularly distasteful. Moreover, the implied promise of a job after graduation may put interns under substantial pressure to perform. Positional competition in the graduate labour market filters down to placement students, making them more malleable and perhaps less likely to complain or resist what are considerable demands on their time and effort during the placement. The monitoring of interns is largely left to employing organisations and conducted against set targets as a performance management system. It could be argued that regular feedback is beneficial to interns and indeed, some seem to welcome the opportunity to engage with their employers and take full advantage of performance development plans to enhance their skills. However, it appears that those interns who are found wanting are gradually set aside. They will not be recommended for prized graduate traineeships, nor will they gain much relevant experience. Thus, for two individuals working in the same organisation the internship experience may be entirely different.

More generally, it appears that universities are perhaps too complacent in their evaluation of internships and wedded to the notion that any work experience is a good experience for their students. It is seen to be sufficient for universities to offer degrees with a year in industry component, to advertise placement opportunities and to congratulate themselves on the number of their graduates who are subsequently employed. However, the evidence from employers is that students are not necessarily prepared for the world of work and that there should be closer communication between industry and university. This foregrounds a demand-led conception of employability with increasing employer intervention in curricula which is potentially at odds with the purpose of higher education (Apple, 1995). Moreover, the evidence that essential skills in ICT work are moving towards relationship management and project management perhaps suggests a review of employability in degree 
programmes. This is not to say that computer science is a less marketable subject than Business with Information Technology for example, however it does imply that if key measures of employability are difficult to identify in one sector of the economy, then trying to generalise across the entire graduate population produces de-contextualised lists containing basic skills of numeracy and literacy, honesty, work ethic such as the loD suggest (2007). There is far greater purchase in anchoring acquired and required skills and by implication employability to particular labour process(es) (James et al., 2013).

\section{References}

Adams, T. and Demaiter, E. (2008), 'Skill, education and credentials in the new economy: the case of informational technology workers', Work Employment and Society, 22(2),pp.351362.

Andrews J. and Higson H. (2008). 'Graduate Employability, 'Soft Skills' Versus 'Hard' Business Knowledge: A European Study'. Higher Education in Europe. 33. 4. pp 411-422

Antonelli, C. (1999) Microdynamics of technological change, London: Routledge

Apple, M. (1995) Education and power London:Routledge.

Ashton, D and Sung, J. (2010) 'Product Market Strategies and Skills Utilisation' Skills in Focus:Skills Development Scotland

Baldry, C, Bain, P, Taylor, P., Hyman, J., Scholarios, D., Marks, A., Watson, A., Gilbert, K., Gall, G.and Bunzel, D. (2007), The Meaning of Work in the New Economy, London:Palgrave.

Bourdieu P and J-C Passeron (1990) ( $2^{\text {nd }}$ Ed) Reproduction in Education, Society and Culture London, Sage

Brackley, A. (1996) Whatever happened to hybrid managers? The short history of the hybrids, BCS Publishing, p. 16 available online at http://archive.bcs.org/bulletin/dec96/what.htm

Brown,P. (2000) "The Globalisation of positional competition" Sociology 34(4),pp.633-653. Brown, P. and Hesketh, A. (2004) The Mismanagement of Talent Oxford: OUP. Costea, B., Amiridis, K. And Crump, N. (2012) 'Graduate employability and the principle of potentiality: an aspect of the ethics of HRM', Journal of Business Ethics, 111,pp.25-36. 
David,M. (2011) "Overview of researching global higher education: challenge, change or crisis?" Contemporary Social Science, 6(2),pp147-163.

Donnelly, R., Grimshaw, D. and Miozzo, M. (2011) "Does the UK have a 'comparative institutional advantage' that is supportive of the IT services sector?, New Technology, Work and Employment, 26(2), pp.98-112.

e-skills UK (2012), Technology insights 2012, London-e-skills

e-skills (2014), The women in IT scorecard, London:e-skills.

Golden, L. And Baffoe-Bonnie, J. (2011) 'Work-study conflict or facilitation? Time use tradeoffs among employed students' in Price, R, McDonal P., Bailey, J. and Pini, B. (eds) Young People and Work, Farnham: Ashgate., pp. 121-142.

Glover, D. Law, S. and Youngman, A. (2002): Graduateness and Employability: student perceptions of the personal outcomes of university education, Research in Post-Compulsory Education, 7(3),pp.293-306

Hagan, D. (2004, January). Employer satisfaction with ICT graduates. In Proceedings of the Sixth Australasian Conference on Computing Education-Volume 30 (pp. 119-123). Australian Computer Society, Inc..

Hesketh,A.(2000) "Recruiting an elite? Employers' perceptions of graduate education and training." Journal of Education and Work 13(3),pp245-271.

Higher Education Statistics Authority (HESA)

Holtgrewe, U. (2014) "New new technologies: the future and the present of work in information and communication technology", New Technology, Work and Employment, 29(1), pp.9-24.

IoD (2007) 'Graduates' employability skills', Institute of Directors skills briefing (December 2007).

James,S.,Warhurst,C., Tholen, G. and Commander,J. (2013) 'What we know and what we need to know about graduate skills', Work, Employment \& Society, 27(6), pp.952-963.

Keep,E. and James,S. (2010) "Recruitment and selection - the great neglected topic." SKOPE Research Paper No 88, Cardiff and Oxford:SKOPE.

Kelan, E. (2006) "Emotions in a rational profession: the gendering of skills in ICT work", Gender, Work and Organization, 15(1), pp.353-368.

Kelsall,K., Kuhn, A. and Poole,A. (1971) "The young science graduate" Higher Education Quarterly,25(3),pp.353-368. 
Klein, M. and Weiss, F. (2011) 'Is forcing them worth the effort? Benefits of mandatory internships for graduates from diverse family backgrounds at labour market entry.' Studies in Higher Education, 36(8),pp.969-1000.

Machin,S. and Vignoles,A (eds) What's the good of education? Princeton:Princeton University Press, pp.147-166.

Marginson, S. (2006) 'Putting 'public' back into the public university', Thesis Eleven, 84,pp4459.

Marks, A. and Huzzard, T, (2010) "Employability and the ICT worker: a study of employees in Scottish small businesses", New Technology, Work and Employment, 25(2),pp.167-181.

Marks, A. and Baldry, C. (2009) "Stuck in the middle with who? The class identity of knowledge workers", work Employment and Society 23(1),pp.49-65.

Marks A., and Scholarios, D. (2008) 'Choreographing a system: skill and employability in software work'. Economic and Industrial Democracy. 29(1) 96-124

Marks, A. and Scholarios, D. (2007) ' Revisiting technical workers: professional and organisational identities in the software industry', New Technology, Work and Employment, 22(2),pp.98-117.

Mayhew K, Deer C and Dua M (2004) "The move to mass higher education in the UK: many questions and some answers" Oxford Review of Education V30 No 1

Morley,L. (2007), "The X factor: employability, elitism and equity in graduate recruitment." Twenty-first Century Society, 2(2),pp.191-207.

Mourshed, M., Farrell, D. and Barton, D. (2012) Education to Employment, designing a system that works, McKinsey and Company,(www.mckinseyonsociety.com).

National Union of Students (NUS), Campaign against unfair, unpaid and illegal internships (www.nus.org.uk/unpaidinternships - accessed 25.4.2013)

Page, L. 'Join the fight against unpaid internships', The Guardian, 7/12/2012.

Reay,D.,Crozier,G. and Clayton,J. (2010) 'Fitting in' or 'standing out': working-class students in UK higher education, British Educational Research Journal 36(1),pp.107-124.

Siebert, S. and Wilson, F. (2013) "All work and no pay: consequences of unpaid work in the creative industries", Work, Employment and Society 27(4),pp711-721.

Van de Werfhorst, Herman G., Alice Sullivan \& Sin Yi Cheung (2003). "Social Class, Ability and Choice of Subject in Secondary and Tertiary Education in Britain". British Educational Research Journal, 29 (1), 41-62. 
Warhurst, C., Lockyer, C. and Dutton, E. (2006), 'IT jobs: opportunities for all?' New Technology,, Work and Employment, 21(1),pp.75-88.

Wilton, N. (2012) 'The impact of work placements on skills development and labour market outcomes for business and management students' Studies in Higher Education, 37(5),pp603620.

Woodfield, R. (2000) Women, Work and Computing. Cambridge: Cambridge University Press. 